\title{
Knowledge Level of Paddy Growers about Farm Mechanization in Paddy Cultivation
}

\author{
Ravi Shankar Chand Reddy, K.P. Raghuprasad and Tanweer Ahmed*
}

Department of Agricultural Extension, GKVK, UAS Bangalore, Karnataka, India

*Corresponding author

\section{A B S T R A C T}

\begin{tabular}{|l|}
\hline K e y w o r d s \\
Paddy cultivation, Farm \\
mechanization, \\
Knowledge, Paddy \\
growers
\end{tabular}

Farm mechanization implies the use of various power sources, improved farm tools and equipment, with a view to reduce the drudgery of the human beings and draught animals, thereby increasing crop production and productivity. The study was carried out to assess knowledge level of paddy growers about farm mechanization in paddy cultivation in Sindhanur and Manvi taluks of Raichur district. Ex post facto research design was employed for the study. Data were elicited from 120 paddy growers using structured interview schedule. Teacher made test was followed to assess the knowledge level of respondents. Implements that were considered in preparation of schedule were mould board plough, harrow, cultivator, rotavator, power tiller, puddler, paddy transplanter, cage wheel, cono weeder, sprayer, combine harvester and thresher Data were analyzed using appropriate statistical tools like frequency, percentage, mean and standard deviation. The results of the study revealed that nearly half $(45.00 \%)$ of the respondents had medium level of knowledge, followed by 31.67 and 23.33 per cent of respondents had high and low level of knowledge respectively.

\section{Introduction}

Paddy is the staple food crop of world's population and it has got paramount importance to Indian economy. Rice being the important staple food for more than half of the world population, also contributes for Indian food security and enhancing rural economy, paddy being major source of energy, provides 60-70 per cent body calorie intake to the average consumer. The need of mechanization in paddy cultivation is very much seen in order to address the problems like drudgery of animals, high cost of production, low working efficiency of farm laborers, low cropping intensity and above all the labour scarcity. From time to time need has been constantly changing and today the major concern is to lower the production cost, increase the quality of work and address the issues of labour scarcity. In spite of promoting farm mechanization among farming community, still majority of farmers are not using mechanization in all the operations, except few critical stages. Knowledge about farm mechanization plays important role adoption of farm mechanization. Hence a study was carried out to assess the knowledge level of paddy growers about farm mechanization in paddy cultivation. 


\section{Materials and Methods}

The study was conducted in Sindhanur and Manvi taluks of Raichur district in Karnataka. From each taluk, three villages were selected and from each village, 20 respondents were selected randomly thus forming 120 sample for the study. Ex post facto research design was employed for the study. Knowledge was operationalied as the body of information understood and retained by the paddy growers about farm mechanization practices. A teacher made test suggested by Anasthi (1971) was employed to measure the Knowledge level of the respondents about the farm mechanization practices. A list of knowledge items were prepared by discussing with experts from agriculture engineering department, agricultural extension and department of agronomy. Each farm implement separate questions were framed to obtain the response from the farmers. The test constituted 65 knowledge items. For each item alternative answers were given. The answers to the question were quantified by giving one score to correct answer and zero score to incorrect answer. Thus, the maximum possible score was 65 and the minimum was zero. The summation of scores of the correct answers for a particular respondent indicates his knowledge possessed by the paddy growers about farm mechanization. The respondents were grouped into three categories using mean and standard deviation as measure of check. Data were collected using structured interview schedule and analyzed using appropriate statistical tools like frequency, percentage, mean and standard deviation.

\section{Results and Discussion}

Knowledge level of the respondents about farm mechanization implements

Table 1 indicates Knowledge level of the respondents about farm mechanization implements. From the study it is revealed that 70.00 per cent of the respondents had knowledge regarding frequency of use of mould board plough and 65.00 per cent of respondents were aware of its depth of operation. With respect to harrow, 72.50 per cent of the farmers had knowledge about to frequency of cleaning blade of harrow and 54.17 per of respondents had knowledge regarding mode of operation of harrow. Since this implement is simple enough in its usage.

Regarding to cultivator, 70.83 percent of the respondents had knowledge regarding use of duck foot cultivator and 59.16 per cent of respondents knew about the mode of operation. Since cultivator is inevitable, to carry out the timely operations. With respect to rotavator, 70.83 percent of the respondents had knowledge regarding use of rotavator and 41.67 per cent of respondents had knowledge about the types of blades used in rotavator.

It is evident that 85.00 per cent of respondents had knowledge regarding uses of power tiller and 60.83 per cent of respondents had knowledge regarding type of implements attached to the power tiller. With respect to Puddler, 73.33 percent of the respondents had knowledge regarding mode of operation and 64.17 per cent of respondents had knowledge about its uses. Paddy transplanter being the most effective farm machinery it is well to 66.67 percent of the respondents further 16.67 per cent of respondents had knowledge regarding spacing in transplanting and depth of operation, whereas hardly few 5.83 per cent of respondents had knowledge regarding age of seedlings to be transplanted which further needs to educate.

The study also revealed that 96.67 per cent of respondents had knowledge about the use of cage wheel and 90.80 per cent of respondents had knowledge regarding to its mode of operation With respect to cono-weeder, 24.17 
per cent of farmers had knowledge about the utility of the cono-weeder and 25.83 per cent had knowledge about its mode of operation (deal width $370 \mathrm{~mm}$ and height $1400 \mathrm{~mm}$ ) and 20.00 per cent of respondents had knowledge about the situation in which cono-weeder is used. Spraying being an important operation in paddy, the results indicated that 98.33 per cent had knowledge use of knap sack and power sprayer, and 34.17 per cent of respondents had knowledge regarding to its duration and validity of sprayer.

Table.1 Knowledge level of the respondents about farm mechanization implements

$(n=120)$

\begin{tabular}{|c|c|c|c|c|c|}
\hline \multirow[t]{2}{*}{ SI. No } & \multirow[t]{2}{*}{ Implements } & \multicolumn{2}{|c|}{ Known } & \multicolumn{2}{|c|}{ Not known } \\
\hline & & No. & $\%$ & No. & $\%$ \\
\hline \multirow[t]{4}{*}{1} & Mould Board Plough & & & & \\
\hline & $\begin{array}{l}\text { After using animal drawn plough at what } \\
\text { extent the un ploughed land is left out }(5 \%)\end{array}$ & 81 & 68.00 & 39 & 32.50 \\
\hline & $\begin{array}{l}\text { Optimum Depth of operation (Depth 15- } \\
30 \mathrm{~cm} \text { ) }\end{array}$ & 78 & 65.00 & 42 & 35.00 \\
\hline & Frequency of use (once in three years) & 84 & 70.00 & 36 & 30.00 \\
\hline \multirow[t]{5}{*}{2} & Harrow & & & & \\
\hline & Optimum depth of operation (Depth 5-10cm) & 65 & 54.17 & 55 & 45.83 \\
\hline & Length of animal drawn harrow (length $3 \mathrm{ft}$ ) & 68 & 56.67 & 52 & 43.33 \\
\hline & Type of blade used (curved blade) & 85 & 70.83 & 35 & 29.16 \\
\hline & $\begin{array}{l}\text { Frequency of cleaning harrow blade (blocked } \\
\text { with more weeds) }\end{array}$ & 87 & 72.50 & 33 & 27.50 \\
\hline \multirow[t]{5}{*}{3} & Cultivator & & & & \\
\hline & Types of cultivator used (Rigid tyne type) & 84 & 70.00 & 36 & 30.00 \\
\hline & $\begin{array}{l}\text { uses of duck foot type cultivator (smoothing } \\
\text { of clods) }\end{array}$ & 85 & 70.83 & 35 & 29.17 \\
\hline & Number of springs in cultivator (springs) & 78 & 65.00 & 42 & 35.00 \\
\hline & $\begin{array}{l}\text { Optimum Depth of operation (Depth 10- } \\
20 \mathrm{~cm})\end{array}$ & 71 & 59.16 & 79 & 40.84 \\
\hline \multirow[t]{4}{*}{4} & Rotavator & & & & \\
\hline & Uses of Rotavator (mixing of residues) & 85 & 70.83 & 35 & 29.17 \\
\hline & Depth of operation (Depth $10-20 \mathrm{~cm}$ ) & 60 & 50.00 & 60 & 50.00 \\
\hline & Type of blades used (L-type and Helicle type) & 50 & 41.67 & 80 & 58.33 \\
\hline \multirow[t]{3}{*}{5} & Power tiller & & & & \\
\hline & $\begin{array}{l}\text { Uses of power tiller (puddling in wet soil \& } \\
\text { transport goods) }\end{array}$ & 102 & 85.00 & 18 & 15.00 \\
\hline & $\begin{array}{l}\text { Type of implements attached to the power } \\
\text { tiller (Rotary plough implements) }\end{array}$ & 73 & 60.83 & 47 & 39.17 \\
\hline \multirow[t]{3}{*}{6} & Puddler & & & & \\
\hline & $\begin{array}{l}\text { Uses of puddler (to make favorable } \\
\text { condition for paddy crop) }\end{array}$ & 77 & 64.17 & 43 & 35.83 \\
\hline & Depth of operation (Depth $15-20 \mathrm{~cm}$ ) & 88 & 73.33 & 32 & 26.67 \\
\hline t & Paddy transplanter & & & & \\
\hline
\end{tabular}




\begin{tabular}{|c|c|c|c|c|c|}
\hline & $\begin{array}{l}\text { Use of paddy transplanter (used to transplant } \\
\text { seedlings) }\end{array}$ & 80 & 66.67 & 40 & 33.33 \\
\hline & $\begin{array}{l}\text { Number of trays required for one acre } \\
\text { transplantation ( } 80 \text { trays) }\end{array}$ & 11 & 9.17 & 109 & 90.83 \\
\hline & $\begin{array}{l}\text { Required spacing in transplanting method } \\
\text { (spacing row to row } 30 \mathrm{~cm} \text { and plant to plant } \\
5-6 \mathrm{~cm})\end{array}$ & 20 & 16.67 & 100 & 83.33 \\
\hline & Depth of operation (Depth 1-2 inches) & 20 & 16.67 & 100 & 83.33 \\
\hline & $\begin{array}{l}\text { Age of seedlings to be transplanted (14-15 } \\
\text { days) }\end{array}$ & 7 & 5.83 & 117 & 94.17 \\
\hline \multirow[t]{3}{*}{8} & Cage wheel & & & & \\
\hline & Use of cage wheel (puddling wet soil) & 116 & 96.67 & 04 & 3.33 \\
\hline & Depth of operation & 109 & 90.83 & 11 & 11.00 \\
\hline \multirow[t]{4}{*}{9} & Cono- weeder & & & & \\
\hline & Uses of cono -weeder (wet land weeder) & 29 & 24.17 & 91 & 75.83 \\
\hline & Depth of operation (width 370mm) & 31 & 25.83 & 89 & 74.17 \\
\hline & $\begin{array}{l}\text { In what situation the operation of cono- } \\
\text { weeder is possible (transplanted field by } \\
\text { paddy transplanter) }\end{array}$ & 24 & 20.00 & 96 & 80.00 \\
\hline \multirow[t]{4}{*}{10} & Sprayer & & & & \\
\hline & $\begin{array}{l}\text { Tank capacity of knapsack sprayer }(9-22.50 \\
\text { liter is tank capacity) }\end{array}$ & 118 & 98.33 & 02 & 1.67 \\
\hline & Mode of operation of power sprayer & 114 & 95.00 & 06 & 5.00 \\
\hline & Validity of power sprayer (8 years) & 41 & 34.17 & 79 & 65.83 \\
\hline \multirow[t]{3}{*}{11} & Combine harvester & & & & \\
\hline & $\begin{array}{l}\text { Functions of combine harvester (harvesting } \\
\text { and threshing) }\end{array}$ & 120 & 100 & 00 & 00 \\
\hline & $\begin{array}{l}\text { Harvesting coverage rate in paddy (1-2ha per } \\
\text { hour) }\end{array}$ & 74 & 61.67 & 46 & 38.33 \\
\hline \multirow[t]{4}{*}{12} & Thresher & & & & \\
\hline & $\begin{array}{l}\text { Uses of Thresher (it separates seeds from } \\
\text { penicle) }\end{array}$ & 120 & 100 & 00 & 00 \\
\hline & $\begin{array}{l}\text { In which crops it is used (green gram, wheat, } \\
\text { maize, sorghum) }\end{array}$ & 117 & 97.50 & 03 & 2.50 \\
\hline & $\begin{array}{l}\text { Capacity of multi crop Thresher (200- } \\
2500 \mathrm{~kg} / \mathrm{hr} \text { ) }\end{array}$ & 82 & 68.33 & 18 & 31.67 \\
\hline
\end{tabular}

Table.2 Overall Knowledge level of respondents about farm mechanization in paddy cultivation

\begin{tabular}{|c|c|c|c|c|c|}
\hline Category & Criteria & Frequency & Percentage & Mean & SD \\
\hline Low & $<($ Mean- $1 / 2$ SD $)$ & 28 & 23.33 & 41.73 & 6.42 \\
\hline Medium & $($ Mean $\pm 1 / 2$ SD $)$ & 54 & 45.00 & & \\
\hline High & $>($ Mean $+1 / 2$ SD $)$ & 38 & 31.67 & & \\
\hline
\end{tabular}


Relatively recent machinery introduced in command areas is combined harvester even then, cent per cent of the respondents were having correct knowledge about functioning of combined harvester and 61.67 per cent of respondents had knowledge about coverage of harvest (1-2ha/hour). In case of thresher, cent per cent of respondents had knowledge regarding uses of thresher followed by 97.50 per cent had knowledge regarding mode of operation, and about 68.33 per cent of them had knowledge regarding capacity of thresher. The paddy growers had remarkable knowledge about cage wheel thresher, combine harvester, sprayer, power tiller, puddler, mould board plough and this is due to the fact that the farmers afford to use these implements which were reaching to their economy, which are most basic and commonly used in the paddy cultivation. As a result they are available in custom hiring centers of the study area and nearly half of respondents had influenced the majority of the respondents to know and adopt the farm mechanization in this region. Further many farmers were not known about implements like cono-weeder, it is due to the fact that the traditionally transplantation of the paddy is done manually where there is no scope for row spacing. Hence it is not possible to use cono-weeder in this situation, with reference to machine transplantation of the paddy, as in case of many paddy growing areas, the growers of this reason also didn't know about its mode of operation, the method of preparation of seedling trays (80trays/acre) and age of seedlings (14-15 days) to be transplanted. These findings are in line with the Meena et al., (2012).

\section{Overall knowledge level of respondents about Farm mechanization in paddy cultivation}

It is evident from Table 2 that nearly half $(45.00 \%)$ of the respondents had medium level of knowledge, followed by 31.67 and 23.33 per cent of respondents had high and low level of knowledge respectively. The probable reasons for above trend may be due to their experience in farming and paddy being labour intensive crop demands more labour forced them to look after other alternatives. Further among the respondents in study area i.e. nearly half $(45.00 \%)$ of the respondents had medium material possession and regularly use few of agricultural implements have made respondents to have considerably high knowledge on mechanization. Because of good social participation and extension contact of the respondents, they had exposed to different kind of farm machineries which further lead to adoption of mechanization in their farms. These findings are in line with the Kanavi (2000).

It can be concluded from above study that majority of the respondents belonged to medium level of knowledge regarding farm mechanization practices in paddy cultivation. This clearly indicates that still a vast scope for the development departments to intervene and improve the knowledge level of farmers about farm mechanization practices by organizing more educational activities and use of media more effectively. Among various operations, paddy transplanting gaining popularity in the region. However, its operation, specific requirements like mat nursery, trays etc., are still in dwindling stage and not easily accessible. Therefore, the Researcher and Extension personnel of the Development Departments should guide and advise the farmers about its advantages and address the operational difficulties clearly.

\section{References}

Anasthi, 1971, A study on knowledge and adoption of recommended mango cultivation practices among farmers of 
Kolar district. M. Sc. (Agri.) Thesis, Univ. Agric. Sci., Bangalore, Karnataka.

Annonymus, 2011, Food and Agricultural Organisation Corporate Statistical Database, FAO, Rome.

Chitra, B. M., 2010, A study on knowledge and adoption of improved practices in selected farming systems of Mandya district, M. Sc. (Agri.) Thesis, Univ. Agric. Sci., Bangalore.

Dhenge, S. A., Mankar, D. M. and Wakle, P. K., 2014, Knowledge level of farmers about integrated pest management practices of paddy. Intl. J. Envt. Sci., 2(6):27-33.

Hiremath, V., 2007, Knowledge and adoption behavior of vegetable growers with respect to Eco-friendly technologies, M.Sc. (Agri.) Thesis (Unpub.), Uni. Agri.Sci., Bangalore.

Kanavi, V. P., 2000, A study on the knowledge and adoption behaviour of
Sugarcane growers in Belgaum district of Karnataka. M. Sc. (Agri.) Thesis, Uni. Agri.Sci., Dharwad (India).

Karpagam, C., 2000, A study on knowledge and adoption behaviour of Turmeric growers in Erode district of Tamil Nadu. M. Sc. (Agri.) Thesis, Uni. Agri.Sci., Dharwad (India).

Meena, S. L., Lakhera, J. P., Sharma, K. C. and Johri, S. K., 2012. Knowledge level and adoption pattern of Rice production technology among farmers. Raj. J. Extn. Edu., 20: 133-137.

Pandya, R. D and Vekaria, R.S., 1994, Knowledge and adoption behaviour of banana growers. Maharashtra J. Ext. Educ., 6: 153-158.

Raghavendra R., 2005, knowledge and adoption of recommended cultivation practices of cauliflower growers in Belgaum district of Karnataka. M. Sc. (Agri.) Thesis Uni. Agri. Sci., Dharwad (India).

\section{How to cite this article:}

Ravi Shankar Chand Reddy, K.P. Raghuprasad and Tanweer Ahmed. 2018. Knowledge Level of Paddy Growers about Farm Mechanization in Paddy Cultivation. Int.J.Curr.Microbiol.App.Sci. 7(10): 3062-3067. doi: https://doi.org/10.20546/ijcmas.2018.710.357 